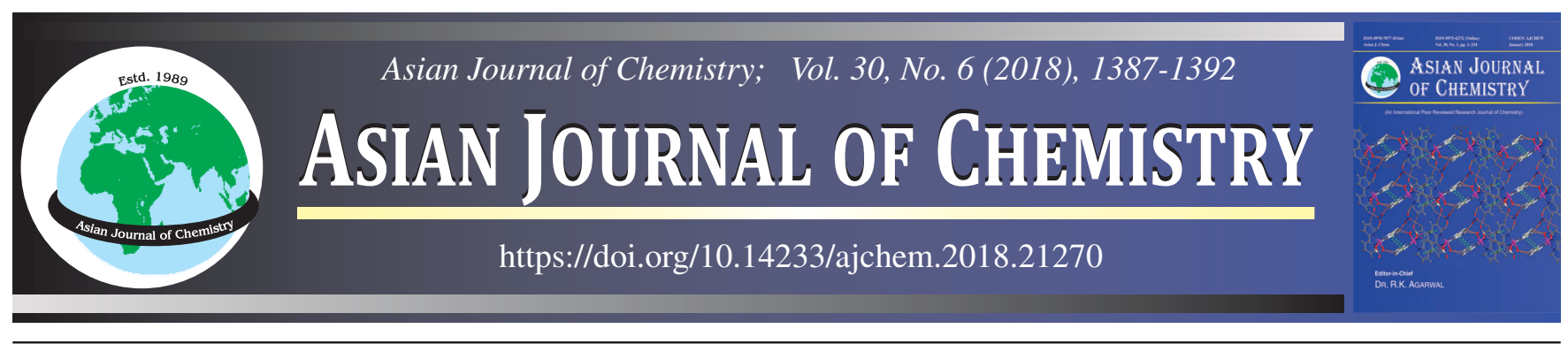

\title{
Efficiency of Ilmenite Photocatalyst Material as Modelling for Antimicrobial Activity
}

\author{
Muhammad Nurdin ${ }^{1, *}$, Nur Arfa Yanti ${ }^{2}$, Suciani ${ }^{1}$, Abdul Haris Watoni ${ }^{1}$, \\ MaUlidiYAH $^{1}$, Andi Aladin $^{3}$ and Dwiprayogo Wibowo ${ }^{1}$
}

\begin{abstract}
${ }^{1}$ Department of Chemistry, Faculty of Mathematics and Natural Sciences, Universitas Halu Oleo, Kendari 93232-Southeast Sulawesi, Indonesia ${ }^{2}$ Department of Biology, Faculty of Mathematics and Natural Sciences, Universitas Halu Oleo, Kendari 93232-Southeast Sulawesi, Indonesia ${ }^{3}$ Department of Chemical Engineering, Universitas Muslim Indonesia, Jln. Urip Sumoharjo, KM 5. Makassar 90231-South Sulawesi, Indonesia
\end{abstract}

*Corresponding author: Tel: +62 81316551674; E-mail: mnurdin06@yahoo.com

\begin{abstract}
Preparation of ilmenite $\left(\mathrm{FeTiO}_{3}\right)$ composite for antimicrobial under UV-visible lights irradiation was carried out to appropriate as a new antimicrobial material. The preparation of $\mathrm{FeTiO}_{3}$ by using sol-gel method was conducted by the titanium tetra-isopropoxide (TTIP) as precursor titania and added $\mathrm{Fe}\left(\mathrm{NO}_{3}\right)_{3}$ as Fe source. Subsequently, the antimicrobial test (Escherichia coli, Staphylococcus aureus and Candida albicans) was carried out under photocatalysis system. The $\mathrm{FeTiO}_{3}$ was formed on $2 \theta$ of $20^{\circ}, 24^{\circ}, 36^{\circ}, 48^{\circ}, 53^{\circ}$ and $62^{\circ}$ having crystal size $53.75 \mathrm{~nm}$. Scanning electron microscopy-energy dispersive X-ray spectroscopy (SEM-EDX) was investigated that the particle sized was under $100 \mathrm{~nm}$ and $\mathrm{Fe}$ element peak was on $6.398 \mathrm{keV}$. The antimicrobial test showedthat the efficiency of $15 \% \mathrm{FeTiO}_{3}$ was active under visible light irradiation to inhibit of E. coli, S. aureus and C. albicans with diameter zone were $18.778,19.889$ and $20.22 \mathrm{~mm}$ respectively.
\end{abstract}

Keywords: Ilmenite, Antimicrobial activity, Photocatalyst.

L

\section{INTRODUCTION}

Currently, nanoparticle materials are becoming the interest of researchers for development in science and technology [1,2]. The development of preparation methods and applications of nano-sized materials has many advantages namely having large surface contact areas and their efficient use because of their small size [3,4]. According to Khan et al. [5] and Maulidiyah et al. [6], the characteristics of nanoparticles depend on their size, distribution, morphology and phase. Nanoparticles have many uses such as detectors, catalysts, surface coating agents and antibacterials $[7,8]$. Materials with nanometer-scale particle size commonly used in commercial products range from 1 to $100 \mathrm{~nm}$ [9].

One of the nanoparticle types that is currently being developed based on titanium dioxide $\left(\mathrm{TiO}_{2}\right)$ and has superiorities of being environmentally friendly, non-toxic and severa other benefits $[10,11]$. However, the reactivity of $\mathrm{TiO}_{2}$ is only active in ultraviolet (UV) light which affects its performance so that the modification of $\mathrm{TiO}_{2}$ material is needed to improve the performance under visible light which expected to be able to utilize sunlight as abundance source in nature [12-14].

The most popular dopant elements which is easily made and found is ilmenite material $\left(\mathrm{FeTiO}_{3}\right)$. It is existence can be found in nature from the extraction process of iron sand leaching $[15,16]$. Based on various studies indicating that the extraction of iron sand produces very little involvement so that the utilization of $\mathrm{FeTiO}_{3}$ is currently less optimized. In addition, it takes long time to obtain $\mathrm{FeTiO}_{3}$ from iron sand. Therefore, an appropriate method for obtaining $\mathrm{FeTiO}_{3}$ as a model of natural ilmenite is to synthesize $\mathrm{FeTiO}_{3}$ using sol-gel method. The sol-gel method is one of the most effective methods to modify materials so it will produce new materials and new properties with size under $100 \mathrm{~nm}$ [17].

Chen [18] has synthesized $\mathrm{FeTiO}_{3}$ using sol gel method with particle size of 20 to $60 \mathrm{~nm}$ that potentially as photocatalyst material for methylene blue dye adsorption. The addition of $\mathrm{Fe}\left(\mathrm{NO}_{3}\right)_{3}$ compound can decrease band gap value of $\mathrm{TiO}_{2}$ by $2.03 \mathrm{eV}$. Raghavender et al. [19] succeeded in synthesizing $\mathrm{FeTiO}_{3}$ by adding $\mathrm{Fe}\left(\mathrm{NO}_{3}\right)_{3}$ and $\mathrm{TiCl}_{4}$ using sol-gel method which has been applied as dye adsorption agent. $\mathrm{FeTiO}_{3}$ containing ferro(II) oxide $(\mathrm{FeO})$ and $\mathrm{TiO}_{2}$ are classified in semiconductor materials as smart materials because they have photoactive properties and respond to visible light. The function of adding material elements to the $\mathrm{TiO}_{2}$ crystal lattice has been extensively studied by various researchers to improve the physical and chemical properties with expectations of providing optimal benefits for human use and utilized as an antimicrobial ingredient $[20,21]$. 
According to Manjunath et al. [22] the addition of $\mathrm{TiO}_{2}$ catalyst with UV light irradiation to inactivate $E$. coli bacteria showed that it has very good performance, while the use of visible light irradiation takes a very long time. $\mathrm{TiO}_{2}$ acts as photocatalyst suppresses the growth of microorganisms by producing hydroxyl radicals $\left({ }^{\circ} \mathrm{OH}\right)$ and reactive oxygen species (ROS) produced during UV light irradiation [23]. The role of hydroxyl radicals an important in inactivating microorganisms by oxidizing phospholipids contained in cell membranes [24]. Kalantari and Emtiazi [25] reported that when ${ }^{\circ} \mathrm{OH}$ reacts with $\mathrm{H}_{2} \mathrm{O}_{2}$ produced from $\mathrm{TiO}_{2}$ and $\mathrm{Fe}$ ions, it can damage the protein structure. The combination of $\mathrm{Fe}$ ions in nanoparticle-sized $\mathrm{TiO}_{2}$ crystal lattice is expected to inactivate pathogenic microbial. Microbes pathogenic are one of the causes of many infections of diseases found. Humid environmental conditions allow the development of bacteria and fungi [26].

Microbes pathogens can be found in several places such as in hospital, bathroom, kitchen, children's playground and other rooms in a house. Several types of harmful bacteria e.g., E. coli and S. aureus. S. aureus can cause skin diseases, infection of surgical wounds and pneumonia and E. coli bacteria can cause diarrhea, stomach cramps and kidney failure [27,28]. In addition, $C$. albicans is one of fungus types that causes candidiasis disease, namely diseases on mouth, mucous membranes, digestive tract and respiratory tract [29]. Candidiasis is an infection of the Candida genus especially $C$. albicans. More than 150 species of Candida have been identified and seventy percent of candidiasis is caused by Candida albicans [30]. So, this study aims to develop $\mathrm{FeTiO}_{3}$ material synthesized using sol-gel method and can be utilized in the industrial field as an antimicrobial desifectant (E. coli, S. aureus and $C$. albicans).

\section{EXPERIMENTAL}

Synthesis of ilmenite $\left(\mathrm{FeTiO}_{3}\right): \mathrm{FeTiO}_{3}$ precursor was prepared from solution 1 in the form of colloidal solution of $\mathrm{TiO}_{2}$ prepared by $4 \mathrm{~mL}$ titanium tetra-isopropoxide (TTIP) of controlled hydrolysis, $0.5 \mathrm{~mL}$ of acetyl acetone and $15 \mathrm{~mL}$ of ethanol (99\%). Solution 2 was $15 \mathrm{~mL}$ of $99 \% \mathrm{EtOH}$ and $2 \mathrm{~mL}$ of distilled water with addition of $1 \mathrm{~mL}$ of $0.1 \mathrm{M}$ acetic acid and added with $0.5 \mathrm{M}$ of $\mathrm{Fe}\left(\mathrm{NO}_{3}\right)_{3}$. The solution mixture was refluxed for $3 \mathrm{~h}$ at $50{ }^{\circ} \mathrm{C}$. Then, $\mathrm{FeTiO}_{3}$ sol was calcined at $450{ }^{\circ} \mathrm{C}$ to obtain $\mathrm{FeTiO}_{3}$ nanocrystal.

Characterizations: The morphology of the synthesized $\mathrm{FeTiO}_{3}$ nanocrystal was observed by using SEM (JEOL, Model 5900LV) which supported by EDX analyze (Oxford) to obtain the composition of elements. The X-Ray Diffraction (XRD) (Shimadzu PC. 6000) to obtain the crystal type and crystal size of $\mathrm{FeTiO}_{3}$. To provide the existence of $\mathrm{Fe}$ and $\mathrm{TiO}_{2}$ by using X-ray fluorescence (XRF) type Epsilon3.

\section{Antimicrobial activity}

Preparation of $15 \%, 10 \%$ and $5 \% \mathrm{FeTiO}_{3}$ sol gel: The $15 \% \mathrm{FeTiO}_{3}$ solution test was prepared by weighing 7.5 $\mathrm{g}$ of $\mathrm{FeTiO}_{3}$ into a $50 \mathrm{~mL}$ flask then diluted and sterilized in an autoclave at $1 \mathrm{~atm}$ pressure at $121^{\circ} \mathrm{C}$ for $15 \mathrm{~min}$ and diluted in concentrations of $10 \%$ and $5 \%$. The positive control solution used was $4 \%$ phenol solution whereas the negative control used in this research was aquadest.
Antibacterial activity test: The antibacterial activity was performed by well-diffusion method. The well method was performed by using 2 median layers, namely solid NA media and semi solid NA. The solid NA was poured into petri dish as base layer and made a well placed on top of the base media. Semi-solid NA was added into the tested bacteria (E. coli and $S$. aureus) of $1 \mathrm{~mL}$ and homogenized using vortex at $\pm 45-50$ ${ }^{\circ} \mathrm{C}$. Then semi solid NA was poured over the base layer (solid NA) where tips hole had been made and filled with $50 \mu \mathrm{L}$ of $\mathrm{FeTiO}_{3}$ and sterile aquadest as negative control and phenol as positive control. Then, it was incubated in an incubator for 24 $\mathrm{h}$ at $37^{\circ} \mathrm{C}$. After the incubation period, measurements of the formed inhibit zone were performed using vernier caliper.

Antifungal activity test: The antifungal activity was performed by the well-diffusion method. This method was performed by using 2 layers namely the solid PDA media and semi-solid PDA. Solid PDA was poured into petri dishes as the base layer and semi solid PDA was poured over solid PDA containing $1 \mathrm{~mL}$ of $C$. albicans. Then, it was discharged with $50 \mu \mathrm{L}$ of $\mathrm{FeTiO}_{3}$ solution and sterile aquadest as negative control and phenol as positive control. Then incubated in incubator for $24 \mathrm{~h}$ at $37{ }^{\circ} \mathrm{C}$ and measurement of inhibition zone using vernier caliper.

\section{RESULTS AND DISCUSSION}

Synthesis of ilmenite by using sol gel method: $\mathrm{FeTiO}_{3}$ nanoparticles were synthesized using the sol-gel method which has advantage namely easy to control the reaction conditions such as $\mathrm{pH}$, temperature and rate of precursor hydrolysis [31]. In this study, $\mathrm{FeTiO}_{3}$ sol was made with TTIP which firstly reacted within acetyl acetone and ethanol. TTIP is the source of nano-sized $\mathrm{TiO}_{2}$ formation by hydrolysis technique. The addition of acetyl acetone served as a ligand for titaniumchelating in order not to produce $\mathrm{TiO}_{2}$ precipitate which characterized by the change of sol to yellow colour. Ethanol served as controlling the rate of hydrolysis because TTIP is easily transformed into $\mathrm{Ti}(\mathrm{OH})_{4}$ when it directly reacts with water [3]. The process of $\mathrm{FeTiO}_{3}$ sol formation with sol-gel method can be seen in Fig. 1A.

$\mathrm{Fe}\left(\mathrm{NO}_{3}\right)_{3}$ was used as $\mathrm{Fe}(\mathrm{II})$ source to form $\mathrm{FeTiO}_{3}$ structure. Based on Chen [18] and Raghavander et al. [19] were used of $\mathrm{Fe}\left(\mathrm{NO}_{3}\right)_{3}$ very effective to serve as $\mathrm{Fe}$ source to form $\mathrm{FeTiO}_{3}$ and decrease the band gap value of $\mathrm{TiO}_{2}$. The composites obtained were then recalcined at $450{ }^{\circ} \mathrm{C}$ for $1.5 \mathrm{~h}$ to remove solvents such as water and ethanol. Besides, the calcination process aims to decompose $\mathrm{Fe}\left(\mathrm{NO}_{3}\right)_{3}$ into $\mathrm{Fe}$ (II) to be inserted in $\mathrm{TiO}_{2}$ crystal [3]. The calcination process will generate $\mathrm{FeTiO}_{3}$ powder which can be seen in Fig. 1B.

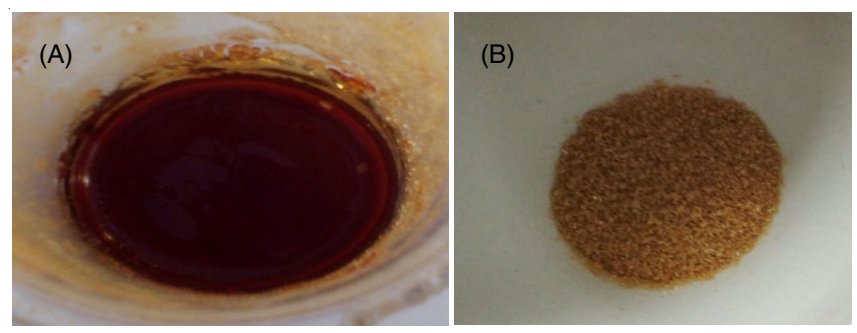

Fig. 1. Synthesized $\mathrm{FeTiO}_{3}$, (A) sol $\mathrm{FeTiO}_{3}$ and (B) Powder of $\mathrm{FeTiO}_{3}$ 
The addition of $\mathrm{Fe}$ ions can increase $\mathrm{TiO}_{2}$ activity in the visible region to inactivate microbes [20]. Increased activity of the material is determined by the value of the band gap energy that affects the movement of electrons in the semiconductor to form hydroxyl radical species. The decrease in the band gap value of $\mathrm{FeTiO}_{3}$ has been reported by several researchers likes Raghavender et al. [19] have successfully synthesized $\mathrm{FeTiO}_{3}$ with a band value gap of $2.80 \mathrm{eV}$ and Chen [18] who reports that $\mathrm{FeTiO}_{3}$ has a band gap value of $2.03 \mathrm{eV}$. From these results, it proved that $\mathrm{FeTiO}_{3}$ is formed between 2.8-2.03 eV so can be applied under visible light.

\section{Characterization of $\mathrm{FeTiO}_{3}$ composite}

Scanning electron microscopy (SEM): The surface characteristics of $\mathrm{FeTiO}_{3}$ prepared by the sol-gel method containing $\mathrm{TiO}_{2}$ and $\mathrm{FeO}$ are shown in Fig. 2. According to Nurdin et al. [7] nanoparticles are particles having size less than $100 \mathrm{~nm}$. Fig. 2 shows $\mathrm{FeTiO}_{3}$ with magnification of 10,000 with the formation of white clots showing the $\mathrm{TiO}_{2}$ compound while the gray clots showing $\mathrm{TiO}_{2}$ covered by $\mathrm{Fe}(\mathrm{II})$.

Emission dispersive X-ray (EDX): The elements content in the natural and synthesized $\mathrm{FeTiO}_{3}$ can be known by using EDX characterization. The characterization results using EDX can be seen in Fig. 3.

Fig. 3 shows the different of elements types the natural ilmenite (Fig. 3A) and synthesized $\mathrm{FeTiO}_{3}$ (Fig. 3B). Fig. 3A explained that the natural ilmenite containing many of elements such as Ti, O, Fe, Na, Al and $\mathrm{Si}$. Whereas, the Fig. 3B shows that the composite contains the three expected elements of $\mathrm{Ti}$, $\mathrm{O}$ and $\mathrm{Fe}$. The peaks indicating the presence of iron at the energy levels of $0.5,6.3$ and $7.1 \mathrm{keV}$, whereas the presence of titanium element at the energy levels of 0.5, 4.3 and $5.0 \mathrm{keV}$. This is in accordance with research performed by Rasidhar $e t$ al. [32] and Raghavander et al. [19]. Fig. 3B shows fewer titanium and iron levels than ilmenite synthesis. EDX results show that natural $\mathrm{FeTiO}_{3}$ still contains many other compounds (Table-1).

X-ray diffraction (XRD): The aim of XRD analysis is to know the structure of $\mathrm{FeTiO}_{3}$ crystal from the synthesis result. Fig. 4 is an XRD comparison between natural and synthesized $\mathrm{FeTiO}_{3}$ composites indicating the presence of $\mathrm{FeTiO}_{3}$.

Fig. 4A shows the presence of 5 specific peaks that the presence of natural $\mathrm{FeTiO}_{3}$ i.e. in $2 \theta$ were $20^{\circ}, 24^{\circ}, 36^{\circ}, 48^{\circ}$,

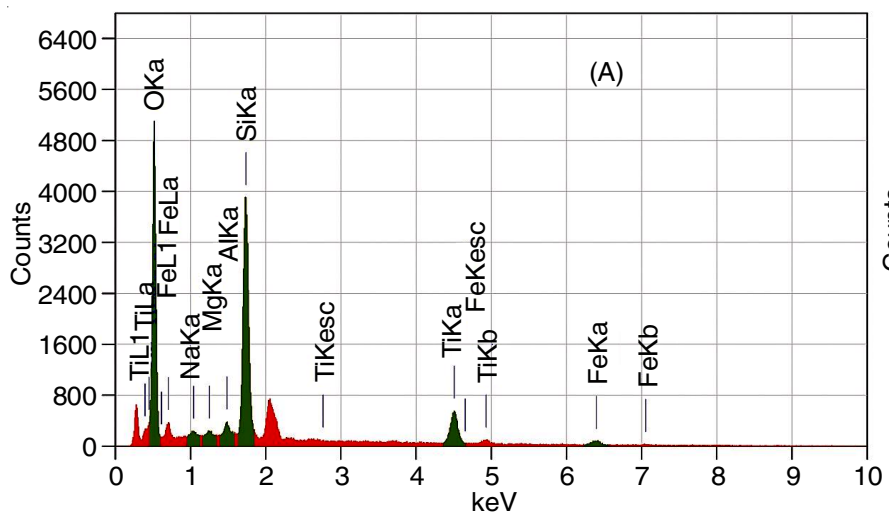

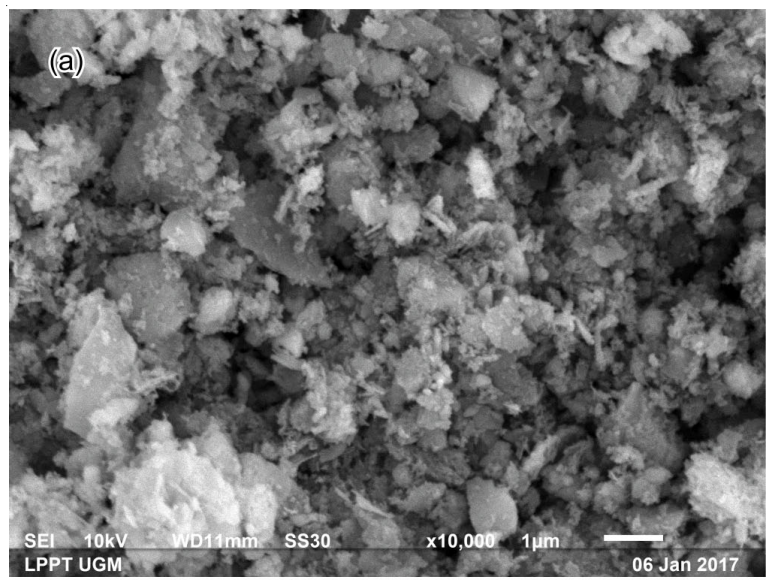

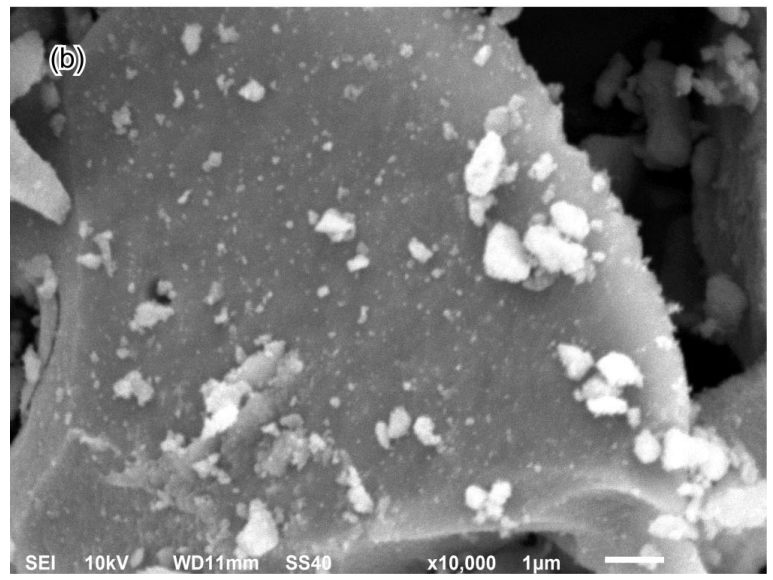

Fig. 2. Morphology of natural ilmenite powder with magnification of 10,000 (a) and synthesized of $\mathrm{FeTiO}_{3}$ powder with magnification of $10,000(b)$

\begin{tabular}{|c|c|c|}
\hline \multicolumn{3}{|c|}{$\begin{array}{c}\text { TABLE-1 } \\
\text { ELEMENTS COMPOSITION OF } \\
\text { NATURAL FeTiO } \text { AND SYNTHESIZED FeTiO }_{3}\end{array}$} \\
\hline \multirow{2}{*}{ Elements } & \multicolumn{2}{|c|}{ Mass $(\%)^{\mathrm{a}}$} \\
\hline & Natural & Synthesis \\
\hline C & 8.50 & - \\
\hline $\mathrm{O}$ & 46.50 & 50.59 \\
\hline $\mathrm{Na}$ & 0.33 & - \\
\hline $\mathrm{Mg}$ & 0.37 & - \\
\hline $\mathrm{Al}$ & 18.38 & - \\
\hline $\mathrm{Si}$ & 16.04 & - \\
\hline $\mathrm{Ti}$ & 16.04 & 47.98 \\
\hline $\mathrm{Fe}$ & 9.07 & 1.43 \\
\hline
\end{tabular}

Fig. 3. EDX spectra of $\mathrm{FeTiO}_{3}$; (A) natural ilmenite and (B) synthesized $\mathrm{FeTiO}_{3}$ 


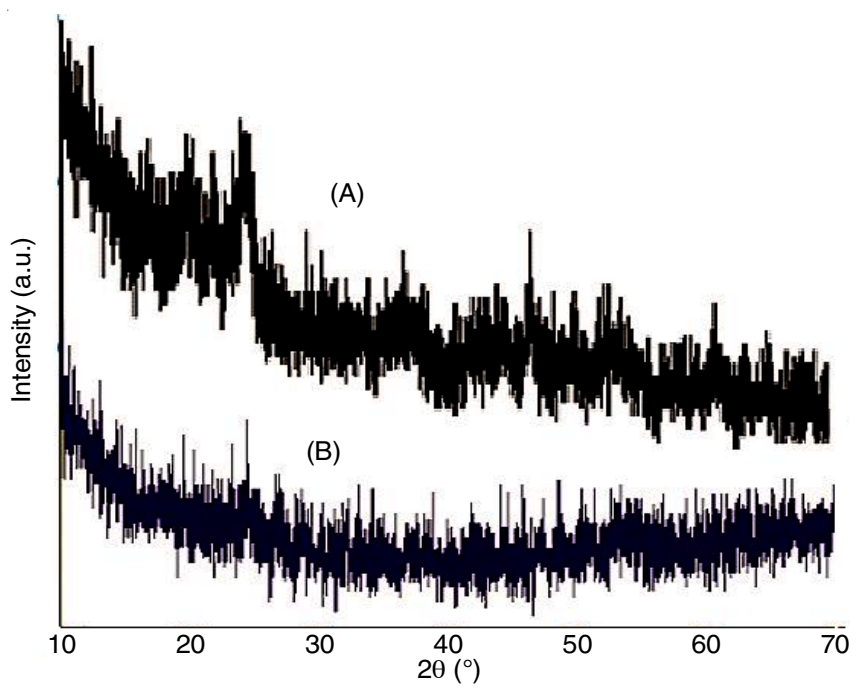

Fig. 4. XRD pattern of $\mathrm{FeTiO}_{3}$; (A) natural $\mathrm{FeTiO}_{3}$ and (B) synthesized $\mathrm{FeTiO}_{3}$

$53^{\circ}$ and $62^{\circ}$. It has a rutile crystal form with a crystal size of $53.75 \mathrm{~nm}$. In addition, Fig. $4 \mathrm{~B}$ the results of XRD difragtogram analysis of synthesized $\mathrm{FeTiO}_{3}$ show the presence of 3 peaks in $2 \theta$ of $24^{\circ}, 36^{\circ} 48^{\circ}$ and $53^{\circ}$ with the crystal size of 54.3362 nm. Raghvander et al. [19] reported that $\mathrm{FeTiO}_{3}$ has particle size below $100 \mathrm{~nm}$. In addition, Chen [18] successfully synthesizes $\mathrm{FeTiO}_{3}$ with particle size of $60 \mathrm{~nm}$.

These results have been adjusted based on JCPDS data No. 291-0773. Chen [18] reported that there are six peaks in the region of $2 \theta=24^{\circ}, 32^{\circ}, 36^{\circ}, 40^{\circ}, 48^{\circ}$ and $56^{\circ}$ with (012), (104), (110) (113) (024) and (116) Miller index which are typical peaks of ilmenite crystals.

X-ray fluorescence (XRF): The synthesis results of $\mathrm{FeTiO}_{3}$ composite were confirmed with XRF data to identify the chemical components in the sample and how great the percentage was and to know the compounds produced from the sol-gel method. The results of XRF characterization can be seen in Fig. 5.

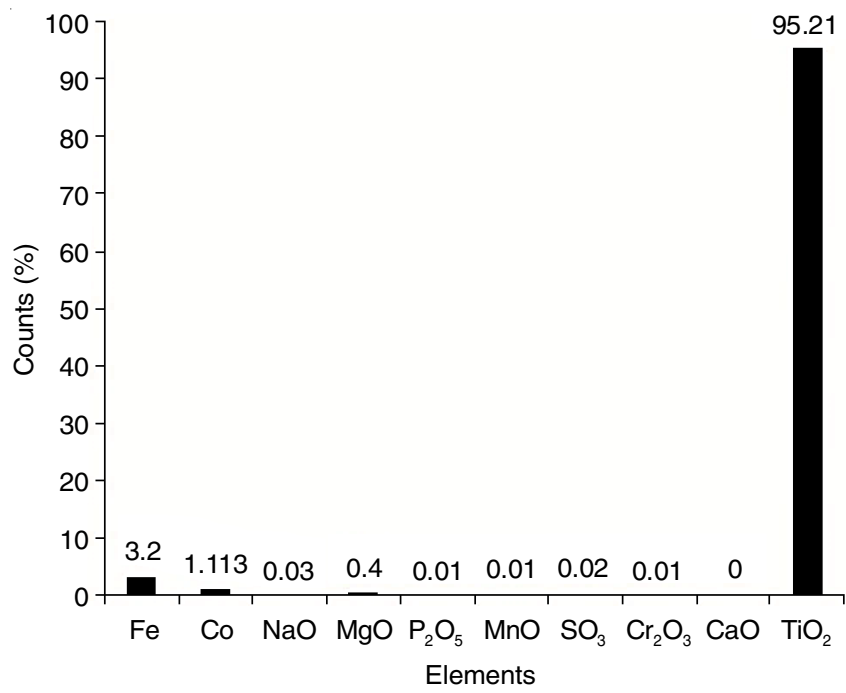

Fig. 5. XRF characterization of synthesized $\mathrm{FeTiO}_{3}$

Fig. 5 shows the results of XRF analysis on $\mathrm{FeTiO}_{3}$ composite, there are 4 compounds with different percentages. There are 2 compounds that have the largest percentage namely $\mathrm{TiO}_{2}$ of $95.21 \%$ and $\mathrm{Fe}$ of $3.20 \%$. The results show that Fe element is inserted in $\mathrm{TiO}_{2}$ crystals to form $\mathrm{FeTiO}_{3}$ compounds. Samal [33] reported that the highest contents of $\mathrm{FeTiO}_{3}$ from iron sand are $\mathrm{TiO}_{2}(50 \%), \mathrm{FeO}(34.20 \%)$, and $\mathrm{Fe}_{2} \mathrm{O}_{3}(12.20 \%)$.

Antimicrobial activity test: $\mathrm{The} \mathrm{FeTiO}_{3}$ composite antimicrobial was conducted against $E$. coli, S. aureus and C. albicans under visible light. Microbial test was conducted qualitatively based on the clear zone width of microbial media [26,27]. Therefore, a material can inhibit the growth of these microbes in the environment is needed.

This study, antimicrobial activity test used negative and positive control. Negative control used aquadest solvent, while the positive control used phenol with $4 \%$ concentration. Phenol solution with 2-4\% concentration is standard for comparison with other desinfectants in inhibiting microorganism. The purpose using positive control to obtain of $\mathrm{FeTiO}_{3}$ compound activity tested. If the clear zone diameter of the $\mathrm{FeTiO}_{3}$ compound is greater than the control zone, it indicates that the $\mathrm{FeTiO}_{3}$ composite material is very effective as an antimicrobial, whereas if the clear zone formed by the $\mathrm{FeTiO}_{3}$ composite material is smaller or even absent, then $\mathrm{FeTiO}_{3}$ is less effective or unusable as antimicrobials.

The composite test of $\mathrm{FeTiO}_{3}$ nanoparticles was performed with two treatments, under visible and UV lights. This was performed to determine the effect of $\mathrm{Fe}\left(\mathrm{NO}_{3}\right)_{3}$ which is expected to improve the $\mathrm{FeTiO}_{3}$ composite performance under visible light. The inhibitory activity of $\mathrm{FeTiO}_{3}$ compound against pathogenic microbes by the diameter of clear zone. The diameter of clear zone produced from each microbe by using visible light can be seen in Table-2 and for the treatment under UV light can be seen in Table- 3 .

TABLE-2

ANTIBACTERIAL ACTIVITY TEST OF

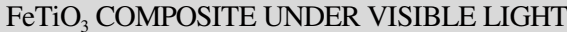

\begin{tabular}{lccccc}
\hline Microorganism & $15 \%$ & $10 \%$ & $5 \%$ & $(+)$ & $(-)$ \\
\hline E. coli & 18.778 & 14.111 & 9.666 & 6,22 & - \\
S. aureus & 19.889 & 15.444 & 12.888 & 6.77 & - \\
C. albicans & 20.222 & 15.777 & 13.000 & 10.33 & - \\
\hline
\end{tabular}

\begin{tabular}{lccccc}
\multicolumn{7}{c}{ TABLE-3 } \\
\multicolumn{5}{c}{ ANTIBACTERIAL ACTIVITY TEST OF } \\
& FeTiO $_{3}$ COMPOSITE UNDER UV LIGHT & \\
\hline Microorganism & $15 \%$ & $10 \%$ & $5 \%$ & $(+)$ & $(-)$ \\
\hline E. coli & 3.667 & 3.444 & 2.889 & 6.220 & - \\
S. aureus & 5.556 & 5.333 & 3.111 & 6.660 & - \\
C. albicans & 17.556 & 14.110 & 11.333 & 10.667 & - \\
\hline
\end{tabular}

Tables 2 and 3 show the increased concentrations that affect $\mathrm{TiO}_{2}$ performance under visible light. $\mathrm{FeTiO}_{3}$ performance is further increased in activating E. coli, S. aureus and C. albicans under visible light than UV light. Based on data, it showed that the $\mathrm{FeTiO}_{3}$ composite can inactivate microbes under visible light. This is in accordance with Kalantari and Emtiazi [25] report that the $\mathrm{FeTiO}_{3}$ was able to inactivate the growth of Bacillus sp. by $50-87 \%$ under visible light. The $\mathrm{FeTiO}_{3}$ composite can inactivate microbes by damaging the cell walls of each microbe. $\mathrm{FeTiO}_{3}$ compounds will react with water and form ${ }^{\bullet} \mathrm{OH}$ and $\mathrm{O}_{2}{ }^{--}$ radicals which will damage bacterial cell walls [34]. 
Fig. 6 explain that the E. coli, S. aureus and C. albicans were interact with $\mathrm{FeTiO}_{3}$ composite compound. The three microbes secrete enzymes to protect cells from oxidation reactions, but when ${ }^{\circ} \mathrm{OH}$ and $\mathrm{O}_{2}{ }^{-}$concentrations are higher than the number of enzymes secreted by E. coli, S. aureus and C. albicans will cause the third cell of the microbe to oxidize which will have an impact on death. Deaths of microbial can also be caused by the activity of ${ }^{\bullet} \mathrm{OH}$ and $\mathrm{O}_{2}{ }^{--}$compounds which damage the cell wall, so that cells will leak and the cytoplasm of cells will out and will experience dryness results in death [34].

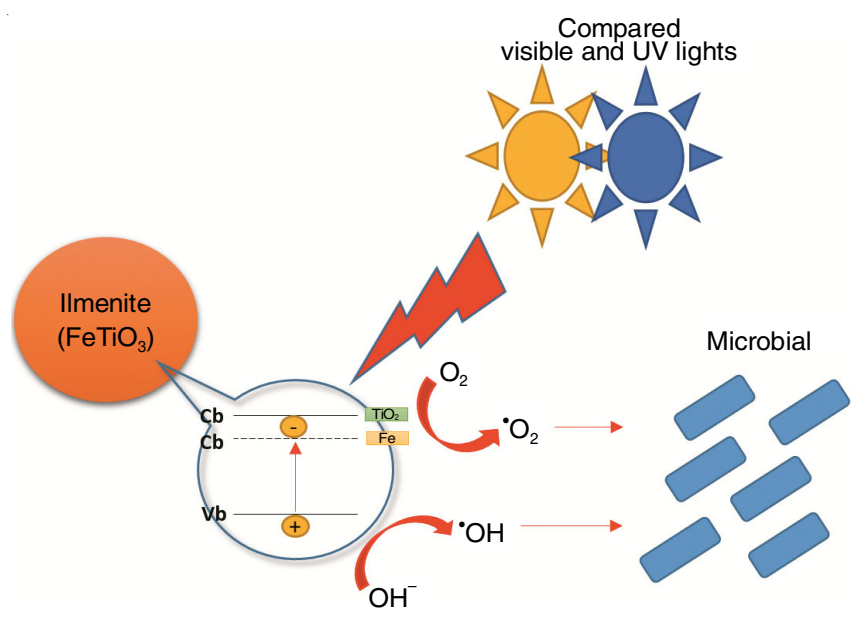

Fig. 6. Purpose of mechanism inactivation of microbials

The $\mathrm{FeTiO}_{3}$ composite is the most active against $C$. albicans than bacteria. This is due to the interaction between ergesterol and radical compounds $\left({ }^{\circ} \mathrm{OH} \mathrm{O}_{2}{ }^{\circ}\right)$ will damage $C$. albicans cell membrane. Antifungal activity depends on the interaction between antifungal compounds with sterols in fungi cell membranes, especially ergosterol. It will experience dryness, due to the formation of interactions between sterols and antibacterials [30].

Tables 2 and 3 data shows that the $\mathrm{FeTiO}_{3}$ composite is more susceptible to damage Gram-positive bacterial cell walls than Gram-negative bacteria. This is due to differences in cell wall structures of both types of bacteria. The cell walls of Gram-positive bacteria consists of peptidoglycan layers that form thick and rigid structures to maintain the integrity of the cell, whereas the cell walls of Gram-negative consist of thin peptidoglycan layers and have layer of wall outside the peptidoglycan layer that makes it difficult for antibacterial compounds to destroy Gram-negative bacteria [35].

The results of this study prove that $\mathrm{FeTiO}_{3}$ composites are more effective in inactivating microbes under visible light compared with UV light. This proves that the change of $\mathrm{TiO}_{2}$ crystal structure by Fe ions effects the change of opto-photonic properties of a material.

\section{Conclusion}

The $\mathrm{FeTiO}_{3}$ successfully synthesized by using the sol-gel method. The SEM indicated that the $\mathrm{FeTiO}_{3}$ nanoparticle has formed under $100 \mathrm{~nm}$. Supported by using EDX to analyze of elements composition on $\mathrm{Ti}, \mathrm{O}$ and $\mathrm{Fe}$ were $47.98 \%, 50.59 \%$ and $1.43 \%$, respectively. The XRD result showed the rutile polymorph formed with crystal size $53.75 \mathrm{~nm}$ in $2 \theta$ were $20^{\circ}$, $24^{\circ}, 36^{\circ}, 48^{\circ}, 53^{\circ}$ and $62^{\circ}$. Antimicrobial activity test (E. coli, $S$. aureus and $C$. albicans) under visible light was a better activity than UV light. The $15 \%$ sol-gel $\mathrm{FeTiO}_{3}$ showed the high-inhibited zone of E. coli, S. aureus and C. albicans were $18.778,19.889$ and $20.222 \mathrm{~mm}$, respectively.

\section{ACKNOWLEDGEMENTS}

The authors acknowledge the financial support from DRPM -Ministry of Research, Technology and Higher Education, the Republic of Indonesia.

\section{REFERENCES}

1. D. Wibowo, Ruslan, Maulidiyah and M. Nurdin, Mater. Sci. Eng., 267, 012007 (2017); https://doi.org/10.1088/1757-899X/267/1/012007.

2. Hikmawati, A.H. Watoni, D. Wibowo, Maulidiyah and M. Nurdin, Mater. Sci. Eng., 267, 012005 (2017); https://doi.org/10.1088/1757-899X/267/1/012005.

3. A.T. Maulidiyah, T. Azis, A.T. Nurwahidah, D. Wibowo and M. Nurdin, Environ. Nanotechnol. Monit. Manag., 8, 103 (2017); https://doi.org/10.1016/j.enmm.2017.06.002.

4. Maulidiyah, H. Ritonga, R. Salamba, D. Wibowo and M. Nurdin, Int. J. Chemtech Res., 8, 645 (2015).

5. I. Khan, K. Saeed and I. Khan, Arab. J. Chem., (2017); https://doi.org/10.1016/j.arabjc.2017.05.011.

6. Maulidiyah, D.S. Tribawono, D. Wibowo and M. Nurdin, Anal. Bioanal. Electrochem., 8, 761 (2016).

7. M. Nurdin, M.Z. Muzakkar, M. Maulidiyah, M. Nurjannah and D. Wibowo, J. Mater. Environ. Sci., 7, 3334 (2016).

8. M. Maulidiyah, D. Wibowo, H. Hikmawati, R. Salamba and M. Nurdin, Orient. J. Chem., 31, 2337 (2015); https://doi.org/10.13005/ojc/310462.

9. L.O. Mursalim, A.M. Ruslan, R.A. Safitri, T. Azis, Maulidiyah, D. Wibowo and M. Nurdin, IOP Conf. Series Mater. Sci. Eng., 267, 012006 (2017); https://doi.org/10.1088/1757-899X/267/1/012006.

10. Maulidiyah, M. Nurdin, Erasmus, D. Wibowo, M. Natsir, H. Ritonga and A.H. Watoni, Int. J. Chemtech. Res., 8, 416 (2015).

11. Maulidiyah, M. Nurdin, E. Widianingsih, T. Azis and D. Wibowo, ARPN J. Eng. Appl. Sci., 10, 6250 (2015).

12. Maulidiyah, M. Nurdin, D. Wibowo and A. Sani, Int. J. Pharm. Pharm. Sci., 7, 141 (2015).

13. Ruslan, M. Mirzan, M. Nurdin and A.W. Wahab, Int. J. Appl. Chem., 12, 399 (2016).

14. M. Nurdin, A. Zaeni, E.T. Rammang, M. Maulidiyah and D. Wibowo, Anal. Bioanal. Electrochem., 9, 480 (2017).

15. M. Nurdin, A. Zaeni, M. Maulidiyah, M. Natsir, A. Bampe and D. Wibowo, Orient. J. Chem., 32, 2713 (2016); https://doi.org/10.13005/ojc/320545.

16. M. Nurdin, Maulidiyah, A.H. Watoni, N. Abdillah and D. Wibowo, Int. J. Chemtech. Res., 9, 483 (2016).

17. H. Ritonga, C. Faiqoh, D. Wibowo and M. Nurdin, Biosci. Biotechnol. Res. Asia, 12, 1985 (2015). https://doi.org/10.13005/bbra/1865.

18. Y.H. Chen, J. Non-Cryst. Solids, 357, 136 (2011); https://doi.org/10.1016/j.jnoncrysol.2010.09.070.

19. A.T. Raghavender, N. Hoa Hong, K. Joon Lee, M.-H. Jung, Z. Skoko, M. Vasilevskiy, M.F. Cerqueira and A.P. Samantilleke, J. Magn. Magn. Mater, 331, 129 (2013); https://doi.org/10.1016/j.jmmm.2012.11.028.

20. D. Sethi, N. Jada, R. Kumar, S. Ramasamy, S. Pandey, T. Das, J. Kalidoss, P.S. Mukherjee and A. Tiwari, J. Photochem. Photobiol. B, 140, 69 (2014); https://doi.org/10.1016/j.jphotobiol.2014.07.007.

21. S.M.H. Al-Jawad, A.A. Taha and M.M. Salim, Optik-Int. J. Light Electron Optics, 142, 42 (2017). https://doi.org/10.1016/j.ijleo.2017.05.048

22. K. Manjunath, L.S.R. Yadav, T. Jayalakshmi, H. Rajanaika and G. Nagaraju, J. Mater. Res. Technol., 7, 7 (2018); https://doi.org/10.1016/j.jmrt.2017.02.001. 
23. Z. Arham, M. Nurdin and B. Buchari, Int. J. Chemtech Res., 9, 113 (2016).

24. J.S. Aprioku, J. Reprod. Infertil., 4, 158 (2013).

25. S. Kalantari and G. Emtiazi, J. Nanosci.: Curr. Res., 1, 101 (2016).

26. Maulidiyah, Sabarwati SH, Safutra E, Nurdin M, Int. J. Pharm. Biol. Sci., 7, 159 (2016).

27. Maulidiyah, Imran, W. Muntu and M. Nurdin, Int. J. Appl. Chem., 12, 347 (2016).

28. J.C.O. Sardi, L. Scorzoni, T. Bernardi, A.M. Fusco-Almeida and M.J.S. Mendes-Giannini. J. Med. Microbiol., 62, 10 (2013); https://doi.org/10.1099/jmm.0.045054-0.

29. P.A. Krishnan, Indian J. Dent. Res., 23, 650 (2012); https://doi.org/10.4103/0970-9290.107384.

30. P.L. Fidel Jr., J.A. Vasquez and J.D. Sobel, Clin. Microbiol. Rev., 12, 80 (1999).
31. C. Burda, Y. Lou, X. Chen, A.C.S. Samia, J. Stout and J.L. Gole, Nano Lett., 3, 1049 (2003); https://doi.org/10.1021/n1034332o.

32. L. Rasidhar, A.R. Krishna and C.S. Rao, J. Biosci. Biotechnol., 5, 193 (2013).

33. S. Samal, JOM, 68, 2349 (2016); https://doi.org/10.1007/s11837-016-1817-1.

34. K. Sunada, T. Watanabe and K. Hashimoto, J. Photochem. Photobiol. Chem., 156, 227 (2003); https://doi.org/10.1016/S1010-6030(02)00434-3.

35. H.M. Yadav, S.V. Otari, R.A. Bohara, S.S. Mali, S.H. Pawar and S.D. Delekar, J. Photochem. Photobiol. Chem., 294, 130 (2014); https://doi.org/10.1016/j.jphotochem.2014.07.024. 